\title{
Negotiating Authority: Local WAE Communities in the World Heritage Convention
}

Małgorzata Trelka, University of Birmingham, Birmingham, UK

E-mail: mtrelka@aol.com

\begin{abstract}
The Operational Guidelines for the implementation of the World Heritage Convention stipulate that local communities and indigenous peoples are an intrinsic part of the identification, nomination, management and protection of World Heritage sites (UNESCO 2019, art. 12). This paper explores the role of local communities in the World Heritage system by critically assessing the implementation of the Convention in a European context through the case study of the Ironbridge Gorge WHS. The case study is contextualised in the representation of indigenous peoples in World Heritage policies negotiating their intellectual and legal authority in the World Heritage process facilitated through heritage bureaucracy. This paper will address the internationally important issue of power relations when it comes to the inclusion of local communities and indigenous peoples in the World Heritage Convention and in heritage practice.
\end{abstract}

Résumé: Les Orientations devant guider la mise en œuvre de la Convention du Patrimoine mondial stipulent que les communautés locales et les peuples autochtones font partie intégrante de l'identification, de la proposition d'inscription, de la gestion et de la protection des biens du patrimoine mondial (UNESCO 2019, article 12). Cet article étudie le rôle des communautés locales dans le système du Patrimoine mondial au moyen d'une analyse critique de la mise en application de la Convention dans un contexte européen, en s'appuyant sur l'étude de cas du Site Ironbridge Gorge. L'étude de cas est contextualisée dans la représentation des peuples autochtones au sein des politiques du Patrimoine mondial alors qu'ils négocient leur autorité intellectuelle et juridique dans la procédure du Patrimoine mondial facilitée par le biais de la bureaucratie du patrimoine. Cet article s'intéressera à la question importante du point de vue international des relations de pouvoir pour ce qui a trait à l'inclusion des 
communautés locales et des peuples autochtones dans la Convention du Patrimoine mondial et dans la pratique du patrimoine.

Resumen: Las Directrices Operativas para la implementación de la Convención del Patrimonio Mundial estipulan que las comunidades locales y los pueblos indígenas son una parte intrínseca de la identificación, nominación, gestión y protección de los sitios del Patrimonio Mundial (UNESCO 2019 art. 12). Este artículo explora el papel de las comunidades locales en el sistema del Patrimonio Mundial mediante la evaluación crítica de la implementación de la Convención en un contexto europeo a través del estudio de caso de Ironbridge Gorge WHS. El estudio de caso se contextualiza en la representación de los pueblos indígenas en las políticas del Patrimonio Mundial que negocian su autoridad intelectual y legal en el proceso del Patrimonio Mundial facilitado a través de la burocracia del patrimonio. Este artículo abordará la cuestión importante internacionalmente de las relaciones de poder cuando se trata de la inclusión de las comunidades locales y los pueblos indígenas en la Convención del Patrimonio Mundial y en las prácticas del patrimonio.

\section{KEYWORDS}

World Heritage, Heritage policy, Local communities, Indigenous peoples, Heritage bureaucracy

\section{Introduction}

Communities defined by $\operatorname{UNESCO}(2007,2)$ as non-state actors are often discussed in the growing body of heritage studies literature as those subjected to the authority of experts (Smith 2006), those empowered in the heritage process (Jameson and Eogan 2013; Jameson 2014, 2016) or as those who manage to negotiate authority in archaeological projects and the formulation of research questions, as well as in interpretation and governance of heritage sites (Schmidt 2014; Atalay 2006).

The legal heritage protection system in a European context is based on the premise of universal value concerned with physical attributes of those values and is implemented through a complex machinery of heritage bureaucracy. This Western system of governance of historic places does not make a distinction between the intellectual claims of different communities in relation to their heritage. Hence, local communities are conflated regardless of whether they have a direct, evidenced link with their local his- 
toric environment or do not claim any such direct connection. The identification of Outstanding Universal Value is based on comparative analysis, and what can be classified as being of universal significance will change according to the expanding criteria for inscription and sophisticated scholarly research. The Western system of heritage governance described by Smith (2006) as "Authoritative Heritage Discourse" gives communities lesser powers as opposed to heritage workers, and this can be exemplified in the historical accounts of the WH Committee meetings, where there was almost no concept of discussing the role of communities in the World Heritage process, with one exception: according to the main aims of the Convention the public were supposed to be educated on its scope in line with article 27 (UNESCO 1972, art. 27).

Hence, the early discussions were concerned with public information activities and how to inform as wide an audience as possible about the concept of the Convention (UNESCO 1978a, 5). At this early stage, the strategy was to create awareness-raising programmes dealing with the objectives of the Convention through different media outlets (UNESCO $1978 \mathrm{~b}, 2)$ and to promote the Convention through governmental machinery at the national level (UNESCO 1978c, 5). This was also the case with ICCROM, as education of the general public was seen as the best way to "awake awareness of the artistic and historical value of monuments and objects" (ICCROM 1973, 26). The force of public opinion was considered as crucial in the successful setting up of monument protection policies. This interaction with the public was envisioned to flow one way: "training [of] public opinion" was seen as necessary to gain public support (ICOMOS 1990, 48).

This one-way process based on education later evolved into methods of interacting with local communities through development of tools which measured the attitudes of communities towards their heritage. These tools were also used to measure the level of communities' moral obligation to preserve monuments, but also for heritage workers to learn what is significant for local communities (Trelka 2019, 87-94).

Different representations of communities in the heritage studies literature depict two main scenarios. Firstly, when communities claim direct associations with a historic place through evidenced ancestral links. Secondly, when they do not. Traditional communities, descendant and indigenous peoples have been subjected to considerable scrutiny by academics and policy makers from various disciplines. These studies are contextualised in the continuity of a community's original association with historic places or objects. This paper focuses on European communities through the case study of the Ironbridge Gorge (the Gorge).

The paper will discuss the role of communities in the quintessentially Western world of heritage bureaucracy and their authority when it comes 
to the interpretation of their own past due to the evidenced link between the historic remains and the original function of those places. The paper will also analyse whether the current system of heritage bureaucracy makes allowances to include those direct descendants in the implementation of the World Heritage Convention at site level. It will scrutinise whether local communities hold any authority when it comes to identification, interpretation and management of their local heritage.

The case study is based on ethnographic research carried out by the author in 2016 in a place designated as a World Heritage Site (WHS), located in the Ironbridge Gorge in the Midlands, England. The site includes distinctive settlements located in the proximity of the River Severn. On the eastern edges are Jackfield and Coalport; Ironbridge is located centrally, and to the west is Coalbrookdale village, while to the north-east the site incorporates parts of Madeley.

These settlements were historically linked to different industries present in the area including: iron smelting, brick and tile works, coal mining, clay production, and the manufacture of decorative tiles.

The Gorge was one of the first sites put forward by the British government to be included on the World Heritage List in 1986 as a symbol of the 18th-century Industrial Revolution.

This research investigates the attitudes of local people with regards to the World Heritage Site and is based on observations and information collected through forty-four semi-structured interviews and surveys conducted in the Ironbridge Gorge. The survey, which was run simultaneously with interviews, was carried out in 2016, and was based on 126 responses collected as part of the author's PhD fieldwork. The case study presented in this paper is based on my PhD thesis titled "When the Heritage Came" World Heritage and local Communities through the prism of Ironbridge Gorge (Trelka 2019).

The case study is set against the backdrop of representations of indigenous peoples in the World Heritage process and it shows that since its inception, the World Heritage system has been evolving and adapting to changing socio-political demands and responding to political pressures which relate to the internationally important issue of the inclusion of communities in the process of identification and management of World Heritage Sites (WHSs). The World Heritage process also involves three organisations working in service to UNESCO's World Heritage Committee: ICOMOS (the International Council on Monuments and Sites), a non-governmental organisation for experts who are engaged in the conservation and protection of cultural heritage places; ICCROM (The International Centre for the Study of the Preservation and Restoration of Cultural Property); and IUCN (the International Union for Conservation of Nat- 
ure), a membership union composed of both government and civil society organisations.

Within World Heritage, the term local community was introduced due to the persuasiveness of indigenous peoples and their struggles to "include the participation of indigenous peoples and local communities in meetings and processes established by the World Heritage Convention" (UNESCO 2000, Annex 5). Although indigenous peoples instigated discussions concerning involvement of communities in the World Heritage process (UNESCO 2000, Annex 5), they were only included in the Operational Guidelines to the World Heritage Convention in 2015 (UNESCO 2015a), much later than local communities. While rights of indigenous peoples are relatively well defined within the UN system (UN 2007), local communities and their rights are not as clearly defined.

This paper reflects on different facets of the authority of heritage experts, especially when contrasted with the authority of economic forces and the narrative of development at national level.

\section{Indigenous Peoples and Their Struggle for the Recognition of Their Rights in the World Heritage Process on the Basis of the Evidenced Link Between Contemporary People and Their Material Culture}

A Sub-commission of the UN Human Rights Commission adopted the following 'working definition' of the term indigenous peoples: "the existing descendants of the people who inhabited the present territory of a country wholly or partially at the time when persons of a different culture or ethnic origin arrived from other parts of the world, overcame them and, by conquest, settlement or other means, reduced them to a non-dominant or colonial condition who today live more in conformity with their particular social, economic and cultural customs or traditions than with the institutions of the country of which they now form part, under a State structure which incorporates mainly the national, social and cultural characteristics of other segments of the populations which are predominant" as outlined in McNeely and Pitt (1985, 62). The politics of recognition of indigenous peoples took place at national level in different cultural contexts, and it can be exemplified in national legislations (e.g. in Australia Aboriginal Land Rights Northern Territory 1976, and Aboriginal Heritage Act 1988). The mistreatment of indigenous peoples, which was often a result of state intervention or private corporations taking land for extraction of natural resources (IUCN 1993a), has led to their ongoing struggle to access their ancestral lands (IUCN 1993a, 11). In an international context, IUCN has been providing strong continuous support for the recogni- 
tion of legal and intellectual rights of indigenous peoples, evident in decisions concerning their rights.

In Principles and Guidelines for the Protection of the Heritage of Indigenous Peoples:

Indigenous peoples are guardians and interpreters of their cultures, arts, and sciences and have the right to determine the "traditional owners" of their own heritage. Heritage of indigenous peoples includes all movable, intellectual, cultural and scientific property. Scientific, agricultural, technical and ecological knowledge and resources, comprise part of indigenous heritage (Posey 1996, 92).

The introduction of cultural landscapes in 1992 marked a change in thinking about communities, since it was less feasible for States Parties to inscribe cultural places without prior engagement with their users and managers, but also because "it was recognised that the cultural criteria failed to incorporate the idea of cultural continuity from prehistoric times to the present-day existence of living traditional cultures" (Lockwood et al. 2006, 456). Re-nomination of Tongariro National Park in 1993 was an important milestone in the $\mathrm{WH}$ process concerning communities; it became the first property to be inscribed on the World Heritage List under the revised criteria describing cultural landscapes. This allowed meanings assigned by indigenous peoples to be represented in the criteria under which the site was re-nominated. The effect of the "Global Study" - which revealed that Europe's monumental heritage representing Christianity and historic towns and other "elitist" architecture was overrepresented in relation to living cultures and "traditional cultures" (UNESCO 1994a)—resulted in recommendations concerning the modification of World Heritage cultural criteria. In Criterion (i) it was proposed that the phrase "unique artistic achievement" be removed, and in Criterion (iii) it was recommended that "[to] bear a unique or at least exceptional testimony to civilisation which has disappeared" be replaced with "bear a unique or at least exceptional testimony to a cultural tradition or to a civilization which is living, or which has disappeared" (UNESCO 1994a, art 7.) This was an important development towards recognition of the intellectual authority/ rights of indigenous peoples. In the World Heritage process prior to 1992, living cultures were simply not considered in the $\mathrm{WH}$ nominations criteria, with the exception of Criterion (vi), concerned with associative values, which could conceptually include narratives of communities but not necessary of local people. In 1994 the WH Committee also adopted the Global Strategy, which together with the introduction of cultural landscapes resulted in the inclusion of a "traditional protection and management mechanism" in the OG to the WHC (UNESCO 1994b, art 24.ii). 
Indigenous peoples managed to challenge the European way of doing archaeology, and indeed undermined its validity in non-European contexts. The Declaration of San Antonio (ICOMOS 1996), which came as a reaction to the Nara Document on Authenticity, emphasised the importance of archaeological remains and their authenticity in linking contemporary communities with past societies. The issue at the heart of the debate pertained to the direct connection between descendants of the archaeological remains left by pre-European cultures of the Americas linked to their identity (ICOMOS 1996 art 5).

During the 35th session of the WHC (UNESCO 2011, art. 15), some of the requests made by the Indigenous Peoples Forum were incorporated into the report on the global state of conservation challenges facing World Heritage properties. A decision was adopted urging States Parties to involve indigenous peoples and local communities in decision making, monitoring and evaluation of the state of conservation of World Heritage properties and their OUV (UNESCO 2011). It also encouraged States Parties to: "Respect the rights of indigenous peoples when nominating, managing and reporting on WHSs in indigenous peoples' territories" (UNESCO 2011, art $15 f)$.

Policy literature produced by IUCN gives indigenous peoples and local communities an equal footing with experts, as opposed to representing communities as passive recipients of education programmes in which they were supposed to be taught about the values of their historic environment. This is exemplified by both the management category and governance type of Protected Areas which makes provisions for conserved areas-declared and run by indigenous peoples and local communities (Dudley 2008, 27). As mentioned earlier in 2015 the OG were amended to include specific references to indigenous peoples in paragraphs 40 and 123 (UNESCO 2015a). The latter coincided with the General Assembly of the States Parties to the Convention adopting a policy for the integration of a Sustainable Development perspective into the World Heritage process which is strong on community aspects, much of this policy being drawn straight from mainstream UN thinking around Sustainable Development Goals (UNESCO 2015b, c).

Despite all the provisions in the World Heritage process for the inclusion of indigenous peoples, in practice, although these policies are certainly challenging the western system of bureaucracy at the same time they are failing to represent indigenous peoples' worldviews in cultural resource management (Pocock and Lilley 2017, 171; DeVries 2014). The conceptual solutions proposed by academia and the heritage industry when analysed on a case study basis have shown that influencing heritage practice is not enough. The current system of cultural resource management "failed Indigenous and descendant communities in addressing their cultural heritage rights and interests and they have been forced to advocate for them- 
selves in a results-oriented way that scholars and practitioners have to-date been unable to do" (DeVries 2019).

\section{Making World Heritage Shared and Universal Through the System of Heritage Bureaucracy}

Within the World Heritage system universality relates to the distinctive realm in which heritage operates-legal heritage protection concerned with the physical attributes of heritage values. This system was conceived to serve a national community of a Nation State often referred to in the literature by the generic term "the wider society" or "the general public". The aim of such a heritage system, where monuments undergo ever-changing historical associations, is depicted in the context of nationalism (Anderson 1983, 4; Lowenthal 1985), governmentality (Foucault 1991, 103; Smith 2006; Waterton and Smith 2009), and universality-heritage-scape (Di Giovine 2009); but regardless of its contexts, the ultimate aim is to provide citizens with a sense of common narrative.

Currently, the UK makes attempts to involve communities in the decision-making process concerning their local heritage through the system of consultation. Conservation Principles and Guidance (Historic England 2017) is a document designed to provide advice on conservation and changes to the historic environment in England. The consultation draft of this non-statutory document stipulates that everyone should be able to participate in sustaining the historic environment (Historic England 2017, 10). According to this policy:

Experts play a crucial role in discerning, communicating and sustaining the established heritage interest of places, and in helping people to refine and articulate the values they attach to places. However expert a specialist may be about a particular piece of heritage, alternative perspectives are valuable as decision-makers and experts may not be aware of the complete range of views held by people who care about the place (Historic England 2017, art. 11)

In line with this policy, local communities living in the Ironbridge Gorge are expected to add "alternative perspectives" to the expert knowledge produced by the heritage process. How they are included in the interpretation of their heritage depends on the level of the community's awareness of legal procedures and public consultations, as well as the application of relevant planning laws and monument protection policies. 


\section{Local Heritage Experts}

There are national/international narratives communicated by heritage workers through different media outlets present in the Gorge. Those narratives influence the way people value their local heritage. Consequently, half of those who responded to the survey said that the UNESCO designation influenced the way they appreciated their local place. One third of residents disagreed with this statement, and a quarter fell into a group of residents who were not sure what World Heritage means (Figure 1).

This statistical data could be interpreted as both a success for heritage organisations tasked with education and communication of World Heritage values in the Gorge and at the same time as a failure, as half of those interviewed negotiate or are simply unaware of the "authorised" values assigned by heritage workers in the UNESCO nomination process. Amongst them are self-selected original communities living in the Gorge, who have their own interpretations of the past deriving from their personal experiences. These communities interact with the WHS through the prism of social history and stories which are part of their living memory. Indeed, their direct relationship with the historical industries, and strong attachment to the place and its history means that they appreciate the place, but not necessarily through the lens of World Heritage. Those direct associations were explained by an interviewee who negotiated the universal World Heritage meanings attached to the place in order to protect his and his community's identity from obliteration.

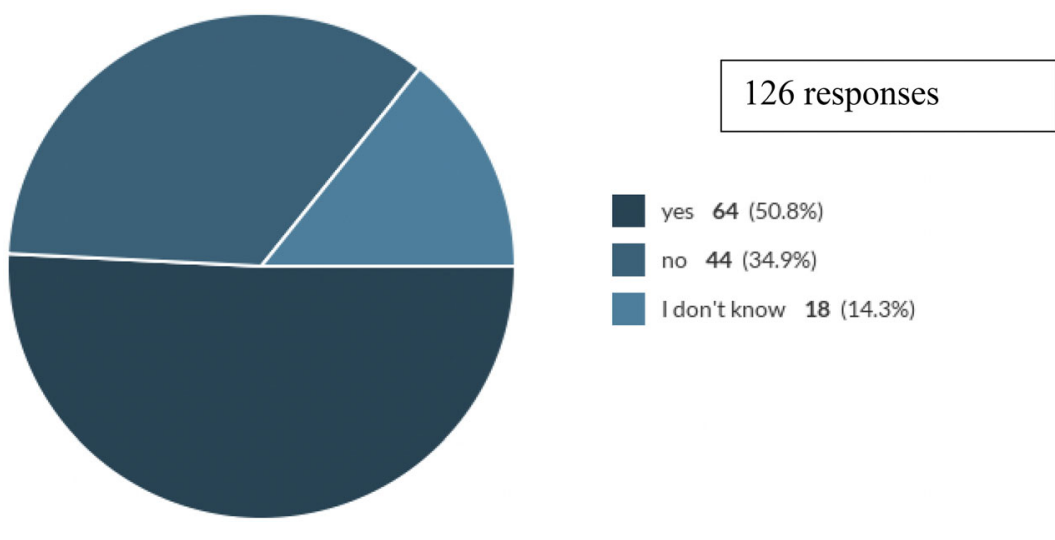

Figure 1. The Ironbridge Gorge is internationally recognised as a World Heritage Site because of its significance. Would you say that UNESCO designation has influenced the way you appreciate your local heritage or changed the way you understand it? 
[World Heritage Site] That's the name of it now. But of course I don't associate with that name, do I? That's the difference. And I say that because if I didn't you will easily translate me to a WH site person, which I am not...

Yeah, describing the people here working on furnaces, pits and in the Foundry and all of that. They were pre-WHS. I cannot put them into the WHS. They didn't belong to the WHS, they worked in the pits and the foundries. We keep their identity and talk about the WHS with them in it, but not in their time.

Original communities engage with their past through the continuity between the past and the present: "When [I'm] talking about people from the past and their lives, they are not dead people, they are living people and it is essential that I tell the truth about their lives" said the interviewee.

I would like to clarify that not every self-defined original community member will have the same attitude to the World Heritage landscape in the Gorge and will support the argument made in this paper. Neither original nor incoming communities represent homogenous groups. However, there are commonalities in attitudes when the responses of original communities are compared with those of incomers who settled in the area mostly in the 1970s and 1980s onwards.

The latter exercise their authority over their properties, which are within the boundaries of the World Heritage site, through the continuous upkeep of their properties, which are part of a World Heritage site. Their intellectual claims were often couched in terms of national belonging expressed in a collective dimension rather than being understood through personal, individual affiliation with the site's industrial past.

In Europe there are communities who feel that they have intellectual authority when it comes to the interpretation of their own past. Their expertise can be developed through scholarship or direct, evidenced links with the original function of a historic place. The communities, which are the focus of this essay, will not necessarily refer to their old ways of life as heritage or tradition because when they worked in mines and furnaces in the "pre heritage era" they did not consider themselves as leading traditional lives and being part of heritage. Hence their notion of Word Heritage is associated with "stuff" which heritage professionals consider as worthy of being on heritage registers. I realised this when a resident explained that "when the heritage came" to the Gorge things dramatically changed for them. 


\section{There are Communities in Europe Who are Experts When it Comes to Interpretation of Their Own Past}

The qualitative research gives an insight into when communities in the Gorge became experts in the interpretation of their local heritage. Such negotiations of meanings attached to the historic landscape take place when different communities interact with the WHS through the prism of personal connections with their ancestral landscape or critical scholarly research. Blists Hill—a reconstructed village-is located within the World Heritage Site; however, it is not recognised by heritage professionals as having an Outstanding Universal Value (OUV). Despite that, this collection of relocated buildings, which some of the communities remember in their original locations, is where they can exercise their authority in communicating the history of the area to visitors. Statistical data from fieldwork based on 116 responses revealed that $45 \%$ of survey participants mentioned Blists Hill among the most important places in the area (Figure 2).

For many local residents, Blists Hill is about continuity rather than nostalgia. It is like a shrine that reminds them of their local area and their ancestors. They would have had ancestors working at the furnace pits and many industries which operated in the area. Hence, the surrounding landscape and its different features have special meaning to them. A former

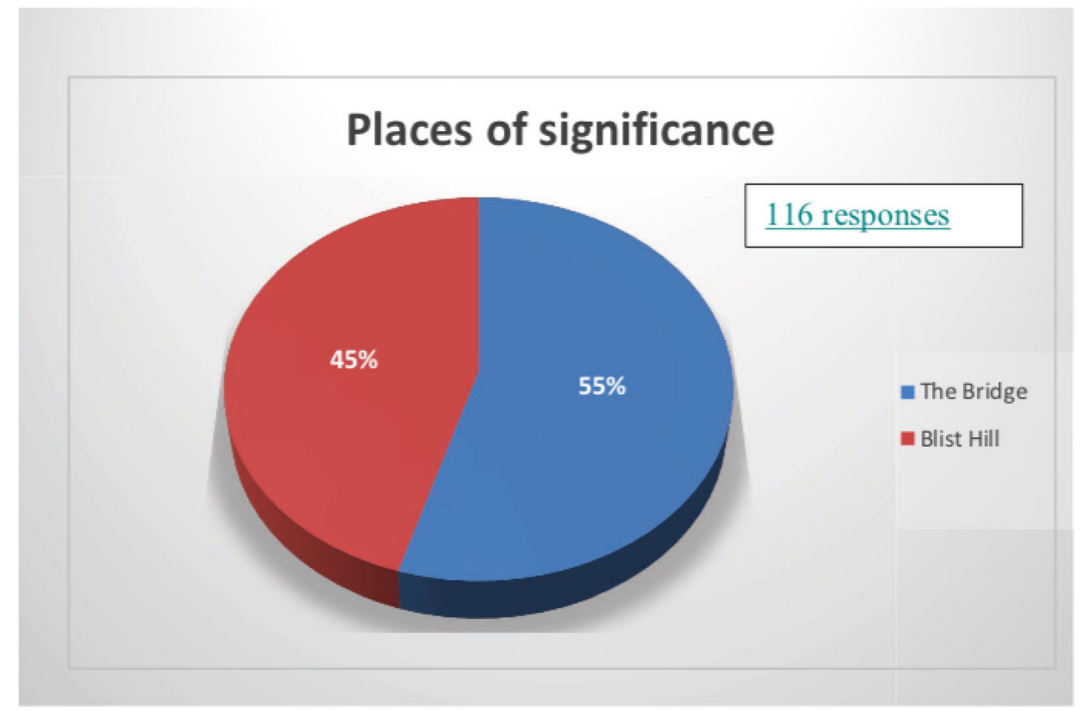

Figure 2. How would you describe your local heritage? Please name sites of significance within the Ironbridge Gorge. (question asked with no prompts) 
miner gave me an almost poetic description of the old pit mounds: when he looks at them he feels he can almost tune into the people who actually formed them.

Local communities can and indeed do protect stories and objects which they care about, especially those that they feel represent their history. An example of a grass-roots engagement within the World Heritage landscape is the local Coracle Society, which attracts relatives of people who were living in the area in the 1920s or who were very close friends with Ironbridge residents of that period. I was told that this feeling of solidarity still survives amongst local people - the feeling "of being together against the big boys out there" said the interviewee. Local communities are particularly interested in coracles because they consider them to be part of their history-a working class history, but also because many of them knew personally or through oral histories a local man called Eustace, who was famous for making coracles (see The Coracle Shed 2018). According to one of my interviewees, they feel that coracle making is part of the story of the area which they can directly relate to (Figure 3 ).

Both the Victorian village and Coracle Society provide a platform to perform and safeguard local traditions. They are places which ensure a sense of security and continuity and spark direct memories of the past, creating a sense of personal familiarity to which local communities can relate.

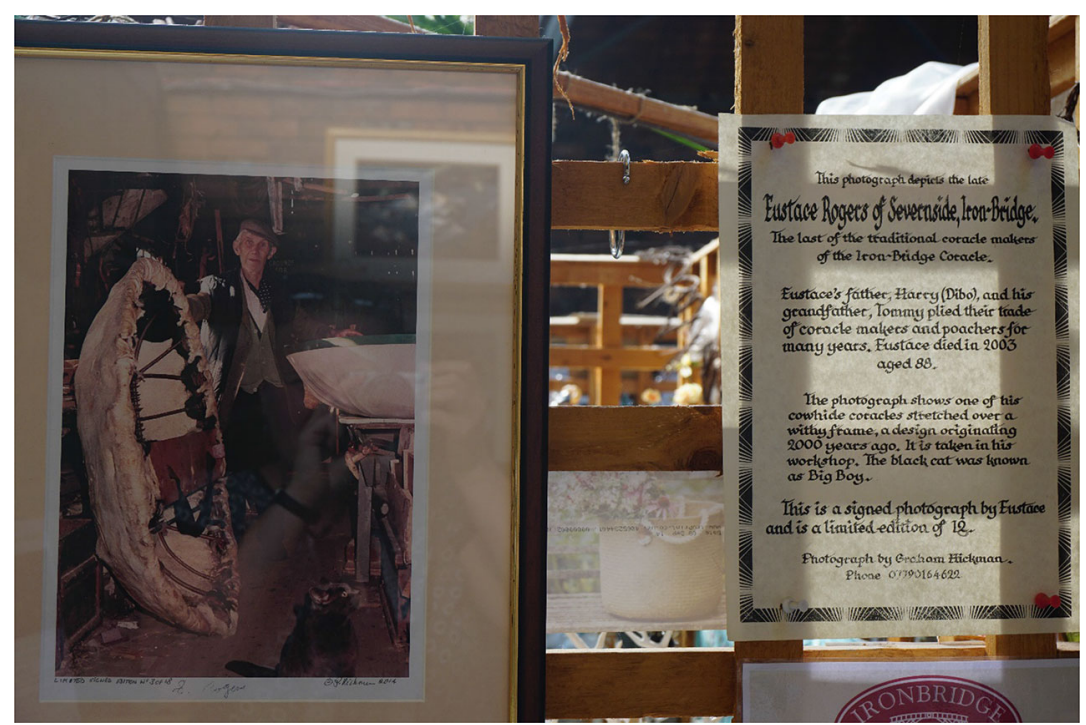

Figure 3. Display about Eustace Rogers in the local antique shop in Ironbridge. (C)Author 
This is where the original communities interpret a past they can easily identify with.

\section{Local Communities Whose Views Should be Considered in the WHS Process have Limited Authority and Powers in the system of Heritage Bureaucracy}

Despite the claims made by policymakers nationally and internationally that local communities' views should be considered in the World Heritage process, the World Heritage concept at its very inception did not effectively consider the role of communities either in the identification of their heritage or in its management. At that time the practice of engaging communities in the listing of their local cultural sites was effectively discouraged by the World Heritage Committee (UNESCO 1994b, art. 14). Hence, local communities from the Gorge were not involved in the identification of the universal significance of the area. 377 sites had been included on the World Heritage list before 1994, and one can assume that those sites were also added without any prior local community involvement.

Despite this strong emphasis in the WH system on inclusion of local communities in the identification, conservation and management of their heritage, an independent report commissioned by IUCN indicates that there is a growing concern about community and rights issues in natural site nominations. The lack of operational frameworks which was identified as an obstacle hindering more effective integration of communities in the World Heritage process (Campese et al. 2009) is also applicable in cultural sites. Larsen examines the technical aspect of checking whether States Parties put in place efforts to respect, protect and fulfil the rights of communities. He concludes that IUCN has no responsibility to conduct full prior evaluations of a given WHS nomination to identify rights issues and engage with affected persons (Larsen 2012, 11). He identifies community and rights issues as being highly "dependent" on the level of civil society reporting and critique (Larsen 2012,18). He also addresses the lack of a concrete set of policy principles and performance indicators on community and rights issues guiding WH Committee decisions on specific site nominations (Larsen 2012). Indeed in 2012 ICOMOS made a plea for greater involvement of communities in decisions concerning World Heritage and criticised the World Heritage Committee for failing to include "such critical representation in the structures of the Committee or in the OG". ICOMOS asserted that there is a need for clear definition of the role of communities in the OG of the Convention (ICOMOS 2012, 12). 


\section{Generic Reflections on the Often Erroneous Perception of the Authority of Heritage Professionals in the World Heritage Process}

Ironically, this expert-driven process subverts the authority of heritage professionals in two ways. Firstly, the inscription and management of World Heritage sites is often determined by political and economic factors. The narrative based on "tourist potential", "income generation for structurally weak areas", "nationalistic agendas" or kudos for politicians who can claim that they put a place on the map, often take precedence over experts' assessments of what is from their perspective worthy of Outstanding Universal Value.

Secondly, the position of "heritage experts" within the local heritage bureaucracy seems to be often challenged and politically weak when it comes to their authority to stop developments that could have a potential negative impact on the physical structures of World Heritage sites. Naturally, World Heritage sites attract developments which are not necessarily in line with the expert idea of preserving the visual integrity and authenticity of those places. These commercial developments do not often respect the views or consider the benefits of local communities. Montgomery Ramírez compares socially unsustainable development to "the language of colonisation" (see Montgomery Ramírez this volume). Contentious projects of this type are discussed during yearly World Heritage Committee meetings in the context of the State of Conservation. The weak position of experts within the World Heritage process is common because they are not politically listened to, and their advice in heritage impact assessments is consequently ignored by their respective governments. This is when nonstate actors, for example local community associations, use the last resort to stop these often dubious developments by triggering article 174 of the Operational Guidelines for the Implementation of the World Heritage Convention (UNESCO 2019, art. 174).

This is done by communities writing to the World Heritage Centre (the Centre) about their concerns relating to the preservation of the historic environment in question. What this means in practice is that they ask for help from the international community to stop developments which they think are damaging their heritage and not benefiting them in any way.

When this process is triggered, the Centre has to verify the sources and formally requests a concerned State Party to the Convention to make explanations in connection with the information received. A response prepared by a State Party to the Convention has to be authorised by the relevant Ministry. This means that when experts present their opinions on the issue, their input is only a form of advice which has no legal force and 
does not need to be taken into consideration by the government. This also means that even when "heritage experts" at national level advise their Minister against a development, during the World Heritage Committee meetings they are technically unable to speak against their own government who employs them. Hence, they often end up following the party line of their politically appointed minister, rather than being able to do what they believe to be right and proper. An honest expression of the frustration of national heritage experts within the World Heritage process is less documented for the reasons detailed above. Nevertheless, the widespread phenomenon of politicisation of the World heritage process is not site specific, as has been widely discussed within critical heritage studies literature (Meskell 2012, 2013, 2014; James and Winter 2017; Bertacchini et al. 2016). Pressures exercised by politicians over heritage professionals all over the world are well documented and accessible for everyone to observe during yearly World Heritage Committee meetings streamed live online. This also applies to the expression of frustration of ICOMOS experts who, similarly to national experts, prepare reports for the World Heritage Committee which are regularly not taken into consideration (ICOMOS 2012).

\section{Conclusion}

The case study is contextualised in the representation of indigenous peoples in World Heritage policies who, in theory, have managed to negotiate their intellectual and legal authority. The analysis of policy and heritage studies literature, however, demonstrates that in practice those legal provisions keep failing indigenous peoples.

The review of policies pertaining to indigenous peoples, however, clearly indicates that the arguments for educating indigenous peoples and traditional communities about their heritage in the same way as European societies, often represented as undefined "local communities" entangled with the quintessentially Western heritage bureaucracy do not stand. This is because indigenous peoples and traditional communities have been recognised as carriers of knowledge about their cultural and natural environment. Their intellectual authority when it comes to interpretation of Indigenous sites, therefore, has been widely recognised in relevant polices.

This paper reflected some of the issues surrounding the authority of experts and local communities in the World Heritage Convention in England and globally. In the international heritage discourse, the movement of indigenous peoples has embraced the idea of direct linkages between current populations and their remains from the past. In Europe, however, when material remains of the past were attributed to particular past peo- 
ples with the aim of tracing the genealogy of present populations back to their imagined origins (Jones 1997, 2), archaeology was feeding nationalism (Lowenthal 1996, 235).

The Conservation Principles and Guidance in England (2017) makes attempts to include "alternative views" in heritage management. There are conceptual and technical problems with the implementation of such provisions in the World Heritage process. Firstly, when communities are not involved in the identification of Outstanding Universal Value and their intellectual claims are not considered in the first place, if they were to be included retrospectively through the management process their local expertise would have to be based on factors ranging from love of the place, feeling at home, national pride, the spirit of the place and its aesthetic value to injustice, the class system, discrimination, exploitation, pollution, environmental degradation and many other associations which bear little relation to the grand UNESCO mission. In the case of the Ironbridge Gorge, their expertise will not necessarily align with the Industrial World Heritage landscape of the Gorge, set predominately in the 18th-century theme of Industrial Revolution constructed by heritage professionals as World Heritage through an elaborate process of scholarship and cultural diplomacy.

Hence, some of the self-selected original communities may have little consideration for "expert authority" when it comes to identification of their past. These communities, like any other communities living in the Gorge, have little influence over determination of what should be protected as "their" World heritage in the heritage system of bureaucracy.

This paper demonstrates that the heritage process negotiated by indigenous peoples and descendant communities outside Europe has also been intellectually challenged in a European context, but rarely with any success. The representation of heritage workers in the World Heritage Convention positions them as those who are expected to have a moral duty to educate the public about heritage. The formal heritage process at an international level fails to acknowledge that engaging people with "their" past, is not always a way forward. In some cases, there are pasts which local communities cannot or, more importantly, do not want to relate to and be engaged with. More emphasis is needed to study how descendant/original communities with direct, evidenced links with their historic landscape can be incorporated meaningfully in the heritage process together with heritage communities in a European context. Heritage professionals have been constantly challenged intellectually and politically. Intellectually challenged by indigenous peoples, descendant communities, diaspora communities and "undefined local communities", and their authority can be questionable when it comes to political power dynamics driven by economic forces. What this research shows is that neither local communities nor heritage workers have real authority in the World Heritage process. 


\section{Acknowledgements}

I would like to thank the local communities of Ironbridge, Madeley, Coalbrookdale, Jackfield, Coalport and Brosley for their generous support with this research. I am especially grateful for their generosity and honesty. Institutional support for the work discussed in this paper, which is based on my PhD, was provided by the University of Birmingham, UK. This Project was funded by AHRC CDA Studentship. Ethnographic interviews were conducted with ethics approval from the University of Birmingham- Application for Ethical Review ERN_15-1684. I would like to thank my friends who commented on the earlier drafts of this paper and in particular I am grateful to Professor Raimund Karl for his constructive comments which helped me to structure my argument.

\section{Open Access}

This article is licensed under a Creative Commons Attribution 4.0 International License, which permits use, sharing, adaptation, distribution and reproduction in any medium or format, as long as you give appropriate credit to the original author(s) and the source, provide a link to the Creative Commons licence, and indicate if changes were made. The images or other third party material in this article are included in the article's Creative Commons licence, unless indicated otherwise in a credit line to the material. If material is not included in the article's Creative Commons licence and your intended use is not permitted by statutory regulation or exceeds the permitted use, you will need to obtain permission directly from the copyright holder. To view a copy of this licence, visit http://creativeco mmons.org/licenses/by/4.0/.

\section{References}

Anderson, B.

(1983). Imagined communities. London: Verso.

Atalay, S.

(2006). Indigenous archaeology as decolonizing practice. American Indian Quarterly, 30(3/4), 280-310.

Bertacchini, E., Liuzza, C., Meskell, L., \& Saccone, D.

(2016). The politicization of UNESCO World Heritage decision making. Public Choice, 167(1-2), 95-129. 
Campese, J., Sunderland, T., Greiber, T., \& Oviedo, G. (Eds.).

(2009). Rights-based approaches: Exploring issues and opportunities for conservation. Bogor: Center for International Forestry Research.

DeVries, M.

(2014). Cultural resource management and aboriginal engagement: Policy and practice in Ontario archaeology. The University of Western Ontario. Retrieved December 15, 2019, from https://ir.lib.uwo.ca/cgi/viewcontent. cgi article $=3847 \&$ context $=$ etd.

(2019). Personal Communication, 16 December 2019.

Di Giovine, M. A.

(2009). The heritage-scape: UNESCO, World Heritage, and tourism. Lanham: Lexington Books.

Dudley, N. (Ed.).

(2008). Guidelines for applying protected area management categories. Gland: IUCN.

Foucault, M.

(1991). Governmentality. In G. Burchell, C. Gordon, \& P. Miller (Eds.), The Foucault effect: Studies in governmentality: With two lectures by and an interview with Michel Foucault (pp. 87-104). Harvester Wheatsheaf: Hemel Hempsted.

Historic England.

(2017). Conservation principles for the sustainable management of the historic environment consultation draft 10th November 2017 [Online]. Retrieved January 2, 2020, from https://historicengland.org.uk/content/docs/guida nce/conservation-principles-consultation-draft-pdf/.

ICCROM.

(1973). Report of the council, AG7/3, Rome, January 1973, ICCROM Archives.

ICOMOS.

(1990). Report of the rapporteur general on the occasion of the opening of the international symposium of ICOMOS. In Summary report 9th general assembly and international symposium ICOMOS, a quarter of century, achievements and future prospects, Lausanne, vol. 6-11, pp. 21-26.

(1996). The declaration of San Antonio [Online]. Retrieved August 28, 2018, from https://www.icomos.org/en/charters-and-texts/179-articles-en-francais/resso urces/charters-and-standards/188-the-declaration-of-san-antonio.

(2012). The World Heritage Convention: Thinking ahead (ideas, proposals and considerations from ICOMS for exploration, Paris, September, 2012.

IUCN

(1993a). Indigenous peoples and strategies for sustainability. Inter-commission task force on indigenous peoples. In Workshop summary report 31 March-2 April, Gland. 
James, L., \& Winter, T.

(2017). Expertise and the making of World Heritage policy. International Journal of Cultural Policy, 23(1), 36-51.

Jameson, J. H.

(2014). International conventions and charters and archaeology presentation. In C. Smith (Ed.), Encyclopaedia of global archaeology (pp. 3948-3954). New York: Springer.

(2016). Management and interpretation of World Heritage through community engagement. Furnace Journal, 5, 6-13.

Jameson, J. H., \& Eogan, J.

(2013). Introduction. In J. H. Jameson \& J. Eogan (Eds.), Training and practice for modern day archaeologists (pp. 4-7). New York: Springer.

Jones, $\mathrm{S}$.

(1997). The archaeology of ethnicity: Constructing identities in the past and present. London: Routledge.

Larsen, P. B.

(2012). World Heritage, and evaluation processes related to communities and rights. Independent review prepared for the IUCN World Heritage programme. Gland: IUCN.

Lockwood, M., Worboys, G., \& Ashish, K.

(2006). Managing protected areas: A global guide. London: Earthscan.

Lowenthal, D.

(1985). The past is a foreign country. Cambridge: Cambridge University Press.

(1996). The heritage crusade and the spoils of history. London: Penguin Books.

McNeely, J. A., \& Pitt, D. (Eds.).

(1985). Culture and conservation: The human dimension in environmental planning, international union for conservation of nature and natural resources. London: Croom Helm Ltd.

Meskell, L.

(2012). The rush to inscribe: Reflections on the 35th session of the World Heritage committee, UNESCO Paris, 2011. Journal of Field Archaeology, $37(2), 145-151$.

(2013). UNESCO's World Heritage Convention at 40: Challenging the economic and political order of international heritage conservation. Current Anthropology, 54(4), 483-494.

(2014). States of conservation: Protection, politics, and pacting within UNESCO's World Heritage Committee. Anthropological Quarterly, 87(1), 217243. 
Pocock, C., \& Lilley, I.

(2017). Who benefits? World Heritage and indigenous people. Heritage and Society, 10(2), 171-190.

Posey, A. D.

(1996). IUCN Traditional resource rights, international instruments for protection and compensation for indigenous peoples and local communities. Gland, Switzerland: University of Oxford.

Schmidt, P. R.

(2014). Rediscovering community archaeology in Africa and reframing its practice. Journal of Community Archaeology and Heritage, 1(1), 37-55.

Smith, L.

(2006). Uses of heritage. New York: Routledge.

The Coracle Shed.

(2018). The Rogers family [Online]. Retrieved August 28, 2018, from http://ww w.coracleshed.org/the-rogers-family.html.

Trelka, M.

(2019). Unpublished $\mathrm{PhD}$ thesis. "When the heritage came" World Heritage and local communities through the prism of Ironbridge Gorge. Birmingham: University of Birmingham.

UNESCO.

(1972). Convention concerning the protection of the world cultural and natural heritage [Online]. Retrieved April 21, 2015, from http://whc.unesco.org/ en/conventiontext/.

(1978a). 2nd session of the World Heritage committee, Washington, D.C., 5-8 September, 2 COM CONF 010 VI.26 [Online]. Retrieved April 20, 2015, from http://whc.unesco.org/en/sessions/02COM.

(1978b). 2nd session of the committee, Washington, D.C., 5-8 September, 2 COM CONF 010 VI.31 [Online]. Retrieved April 20, 2015, from http://whc.u nesco.org/en/sessions/02COM.

(1978c). 2nd session of the committee, Washington, D.C., 5-8 September, COM CONF 010 VI.29 [Online]. Retrieved April 20, 2015, from http://whc.u nesco.org/en/sessions/02COM.

(1994a). Report of the expert meeting on the 'global strategy' and thematic studies for a representative World Heritage list, UNESCO Headquarters, 20-22 June, WHC-94/CONF.003/INF.6. Paris: UNESCO [Online]. Retrieved July 28, 2018, from http://whc.unesco.org/archive/global94.htm.

(1994b). Operational guidelines for the implementation of the World Heritage Convention. Paris: UNESCO [Online]. Retrieved July 28, 2018, from http s://whc.unesco.org/archive/opguide94.pdf. 
(2000). Report from the World Heritage committee 24th session, 27 November-2nd December, Cairns, Australia, WHC-2000/CONF.204/21, Annex 5, Paris, 16 February 2001, Submission to the World Heritage committee from a forum of indigenous peoples assembled in Cairns, Australia, 24 November [Online]. Retrieved July 28, 2018, from https:// whc.unesco.org/archive/repcom00-annexes.htm\#annex5.

(2007). Evaluation of the results of the implementation of the committee's strategic objectives proposal for a 'Fifth $C$ ' to be added to the strategic objectives [Online]. Retrieved August 28, 2018, from https://whc.unesco.org/archiv e/2007/whc07-31com-13be.pdf.

(2011). Global state of conservation challenges of World Heritage properties, 35 COM 12E, 35th session of the Committee Paris, France 19-29 June, WHC-11/35.COM/20, Paris, 7 July [Online]. Retrieved April 10, 2015, from http://whc.unesco.org/en/decisions/4406/.

(2015a). Operational guidelines for the implementation of the World Heritage Convention. Paris: UNESCO [Online]. Retrieved July 28, 2018, from http s://whc.unesco.org/document/137843.

(2015b). The World Heritage Convention and sustainable development, WHC-15/ 39.COM/5D Decision: 39 COM 5D. Retrieved July 28, 2018, from http s://whc.unesco.org/archive/2015/whc15-39com-INF.19.pdf.

(2015c). Policy for the integration of a sustainable development perspective into the processes of the World Heritage Convention, RES20 GA 13 [Online]. Retrieved August 28, 2018, from http://news-1387-1.pdf.

(2019). Operational guidelines for the implementation of the World Heritage Convention. Paris: UNESCO [Online]. Retrieved July 28, 2018, from https:// whc.unesco.org/en/guidelines/.

United Nations.

(2007). Declaration on the rights of indigenous peoples [Online]. Retrived January 28, 2020 from https://www.un.org/development/desa/indigenouspeoples/ wp-content/uploads/sites/19/2019/01/UNDRIP_E_web.pdf.

Waterton, E., \& Smith, L.

(2009). Heritage, communities and archaeology. London: Duckworth.

Publisher's Note Springer Nature remains neutral with regard to jurisdictional claims in published maps and institutional affiliations. 